ISSN:

Print - $2277-0755$

Online - $2315-7453$

(c) FUNAAB 2019

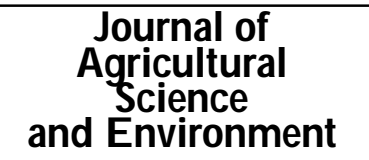

\title{
POTENTIALS AND CHARACTERISTICS OF LANDSAT IMAGERY IN RELATION TO LAND USE / COVER IN OKITIPUPA METROPOLIS, ONDO STATE, NIGERIA
}

\author{
1A. O. TOBORE, 2G. OYERINDE, 3B.A. SENJOBI AND 4T.O. OGUNDIYI
}

1,3,4D epartment of Soil Science and Land Management, Federal University of Agriculture, Abeokuta, Nigeria

2D epartment of Soil Science, Faculty of Agriculture, University of Abuja

*Corresponding Author: anthontobore@ gmail.com Tel: +2348108840248

\begin{abstract}
Landsat satellite imagery plays a crucial role in providing information on land use/cover modifications on local, regional, and global scales, especially where aerial photographs are missing. Monitoring land -use changes from past to present tends to be time-consuming especially when dealing with groundtruth information. Determining the past and current land-use change on Earth's surface using Landsat imagery tends to be effective and efficient when high-resolution imagery is unavailable. This study employed the use of Landsat satellite imagery to assess the past and present land use/cover using supervised classification and Normalized Difference Vegetation Index (NDVI). The result of the supervised classification land use/cover showed that forest cover and woodland undergo rapid loss, while farmland, wetland, built-up, and waterbodies tend to experience gradual loss. The NDVI demonstrated that farmland and forest cover was the most affected land use/cover. Hence, land use/cover of the study area is affected by human activities, such as intensive farming, population size, and deforestation.
\end{abstract}

Keywords: LandSAT Imagery; land use/cover; Normalized Difference Vegetation Index; Supervised Classification

\section{INTRODUCTION}

Landsat satellite imagery has gained global acceptance in providing robust information on land use/ cover change assessments due to its availability and accessibility. One of the abilities of Landsat satellite imagery is to detect and monitor land use/ cover changes for short and long term change. These changes are usually caused by direct (or proximate causes) or indirect changes (Matthiesa and Karimov, 2014). The growing population and subsequent pressure on soil and land resources to produce food calls for monitoring and evaluation of the direction of the resource use and associated changes.

Sub-Saharan West Africa has witnessed widespread land-use changes due to deforestation (Ibrahim $\&$ al., 2015; O yerinde $\notin$ al., 2015). Nigeria loses a large hectarage of land every year to desert encroachment especially in the fifteen (15) Northern States that account for about $68.38 \%$ of the Country's total land area (Ebenezer, 2015). In the face of degrading land as a result of land use, $\mathrm{Ni}$ - 
geria also has the highest population growth rate (Oyerinde $\&$ al., 2015). Most studies made comparisons with land-use change without assessing the potentials and characteristics of Landsat imagery such as Normalized Difference Vegetation Index (NDVI) which can be used to assess deforestation of vegetation loss. One of the principal goals of this study was to use the potential and characteristics of Landsat imagery to assess the land use/ cover of the study area using a supervised classification algorithm and Normalized Vegetation Index in Envi 5.1 and ArcGIS 10.5 environment. It is therefore expedient to investigate the potential and characteristics of Landsat satellite imagery on land use/ cover changes of the study area for sustainable development.

\section{MATE RIALS AND METHODS Description of the study area}

This study focuses on Okitipupa Local Government Area (LGA). O kitipupa LGA is one of the eighteen (18) LGA in Ondo State, Nigeria. It lies between Latitude $6^{\circ} 25^{\prime}$ and $6^{\circ} 30^{\prime} \mathrm{N}$ and Longitude $4^{\circ} 35^{\prime}$ and $4^{\circ} 48^{\prime} \mathrm{E}$ within the Tropical rainforest zone of Nigeria. It has an area of $803 \mathrm{~km}^{2}$ and a population of 233,565 at the 2006 census. The area has two distinct geological formations; the northern part which comprises of Precambrian Basement Complex Granitic Rocks and the recent to tertiary sandy sediments in the central and southern parts of the local government area. The mean annual temperature is $27.0^{\circ} \mathrm{C}$ and precipitation has a mean of $1900 \mathrm{~mm}$ with total annual rainfall often over $2000 \mathrm{~mm}$ (Ajayi \& al.,2010). The digital elevation model and the soil map were used in line with the easy assessment of the land use/ cover of the study (Fig 1 and 2).

Fig 1: Digital Elevation Model of O kitipupa Local Government Area (LGA) in Ondo State, Nigeria (The study area)

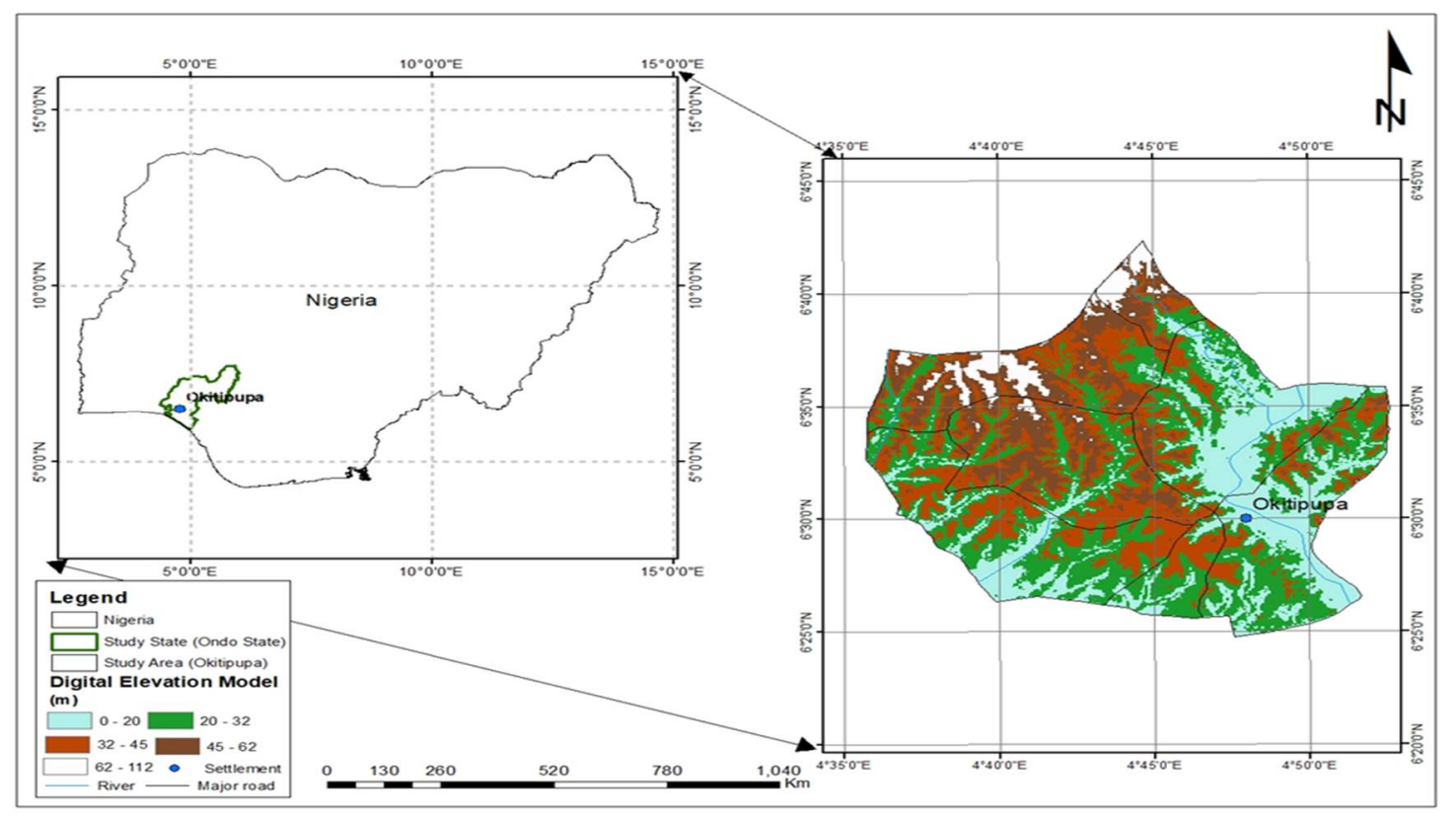

Fig 1: Digital Elevation Model of 0 kitipupa Local Govemment Area (LGA) in Ondo State, Nigeria (The study area). 


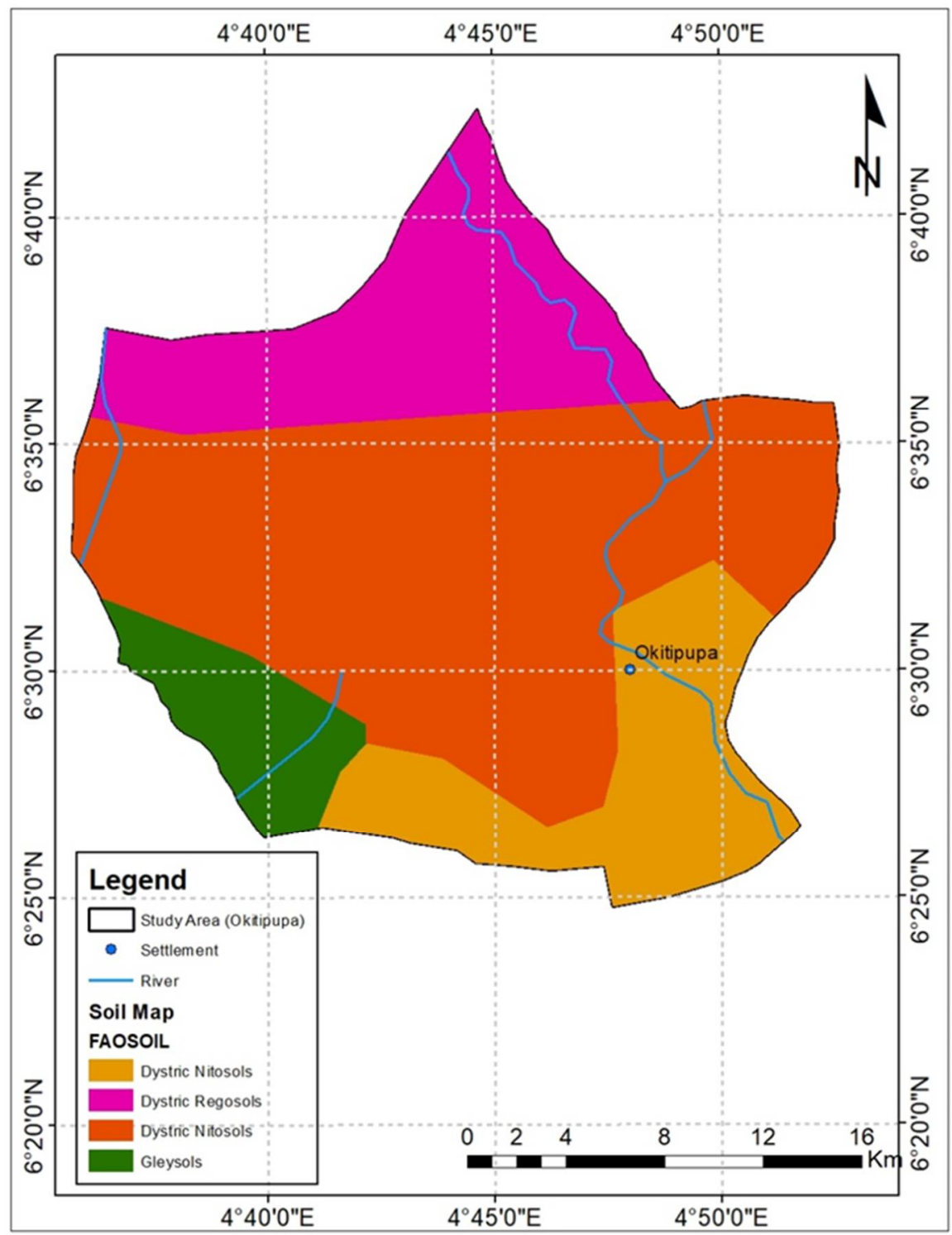

Fig 2: Soil map of 0 kitipupa Local Government Area (LGA) in 0 ndo State, Nigenia (the study area) 


\section{STUDY METHODS}

Data Description and Image Processing

Multi-spectral Landsat 8 enhanced thematic mapper (ETM) satellite data for the years 1999 and 2019 were acquired from the United States G eological Survey (USG S) to assess the land use/ cover change of the study area. The Landsat 8 ETM image was first projected to World Geographic System (WGS) 84 to bring it to the same projection with the shuttle radar topographic mapper and soil map of the study area. The image was initially enhanced to differentiate the various brightness values which could lead to contradictory appearance as a result of identical surfaces appearing on the image. The bands 4, 32 were used to process the image through ENVI 5.1 remote sensing software. The band combination 4, 3, 2 is the standard "false color" composite. Band 3 was used to discriminate the healthy vegetation and also used to exhibit more contrast than bands 1 and 2 because of the reduced effect of atmospheric attenuation. Band 4 was used to define water bounda-

strong red hue with band 4 sensing peak chlorophyll reflectance in which human eyes can easily discriminate subtle tone variations in this color. Therefore, the wetter the soil, the darker it appears, because of the infrared absorption capabilities of water.

\section{Land use/ cover Assessment}

The land use/ cover map of the study area was prepared using Landsat satellite imagery. The potential and characteristics of the images used were shown in table 1 . The images obtained from the Landsat image are classified into six (6) land use/ cover classes based on the Maximum Likelihood Supervised Classification (MLSC) technique (Table 2). The MLCS operation is carried out due to its good performance and easy classification algorithm (Anderson, J. R. 1976: Biro, \& al., 2013). The MLCS were based on Anderson modified level II classification scheme. The Area of Interest (AOI) for land use/ cover features were further identified and assigned value for easy classification.
\end{abstract} ries. The whole image was displayed as a

Table 1: Attribute of the Landsat imagery used in the study

\begin{tabular}{llllll}
\hline Acquisition & $\begin{array}{l}\text { Spatial } \\
\text { Resolution }\end{array}$ & $\begin{array}{l}\text { No of } \\
\text { bands }\end{array}$ & Sun Elevation & Sun Azimuth & $\begin{array}{l}\text { Radiometric } \\
\text { Correction }\end{array}$ \\
\hline 13/ 12/ 1999 & 30 meters & 8 & 50.29 & 140.57 & Yes \\
$11 / 02 / 2019$. & 30 meters & 11 & 53.83 & 126.04 & Yes \\
\hline
\end{tabular}

\title{
Table 2: Description of Land categories
}

\begin{tabular}{lll}
\hline No & Class name & D escription \\
1 & Built-up Area & Residential, commercial, and industrial services, \\
2 & Forest cover & Mixed forest and grass \\
3 & Wetland & Marsh, swamps, bog, and fen \\
4 & Farmland & Rainfed cropping, planted cropping areas. \\
5 & Bushland/ woodland & Sparse flora and fauna \\
6 & Waterbodies & River, wetlands, lakes, ponds, and reservoirs.
\end{tabular}


POTENTIALS AND CHARACTERISTICS OF LANDSAT IMAGERY IN RELATION...

\section{Change D etection T echniques N ormalized Difference Vegetation In- dex}

Vegetation indices derived from satellite remote sensing data are one of the primary sources of information for monitoring of the Earth's vegetation cover (Gilabert, $\notin$ al., 2002). Vegetation indices are usually developed to extract vegetation information from two or more spectral bands. In this study, land use/ cover changes were assessed with NDVI for the years 1999 and 2019. NDVI is a technique that separates green vegetation from other surfaces, since the chlorophyll of healthy green vegetation absorbs red light for photosynthesis and reflects in the near-infrared (NIR) wavelengths due to scattering caused by internal leaf structure (Wilson and Sader, 2002). The index is calculated using equation (1):

$N D V I=\frac{N I R-R E D}{N I R+R E D}$

Where: NIR is the spectral reflectance measurements in the near-infrared regions of band 5 Red is the Spectral reflectance measurements in the visible red of band 4

Land use/ cover Classification Accuracy Classification accuracy was performed on land use/ cover features from 1999 and 2019 images (Congalton and Green, 1999). In the absence of aerial photographs, reconnaissance and ground-truthing proved to be very helpful in assessing the accuracy of the classification of the image. Google Earth Imagery was also used to confirm the land use/ cover classification. The overall classifi- cation accuracy was computed by dividing the sum of all the correctly classified pixels (diagonal of the confusion matrix) by the total number of pixels in the confusion matrix while the Kappa coefficient is the proportion of agreements after the chance agreement has been excluded. The calculation of the Kappa coefficient is similar to the Chi-square and is computed using the formula below:

$K=($ Overall classification accuracy - expected classification accuracy) /

1(expected classification accuracy)

\section{RESULTS AN D DISCUSSION Result of $L$ and use/ Cover mapping}

Land use/ cover of the study area showed that forest cover in 1999 covered $93.2 \mathrm{~km}^{2}$ $(43.7 \%)$, forest cover in the year 2019 has 72.9 (12.0\%), farmland having $264.7 \mathrm{~km}^{2}$ $(43.7 \%)$ while Farmland in the year 2019, covered $374.2 \mathrm{~km}^{2}(62.1 \%)$. The changes (2019) observed in built-up and farmland tend to increased and this could be as a result of land development in the study area.
The land use/ cover changes also showed that farmland has tremendously gained or increased which tends to affect forest cover, bushland/ woodland, and waterbody in the study. The result was correlated with that of Oyinloye (2010) who noted that Akure has experienced a rapid conversion of agricultural areas to urban (non-agricultural) land uses using the satellite imageries of 1972, 1986 and 2002. Table 3 shows the change analysis of the land use/ cover of the study area. 
Table 3: Change analysis of land use/ cover between the years 1999 and 2019

\begin{tabular}{lccccccc}
\hline $\begin{array}{l}\text { Land use/ } \\
\text { Cover }\end{array}$ & Class-id & \multicolumn{2}{c}{1999} & & 2019 & $\begin{array}{c}\text { Change } \\
\text { trend }\end{array}$ & $\begin{array}{c}\text { Change } \\
\text { trend }\end{array}$ \\
& & $\begin{array}{c}\text { Area } \\
\left(\mathrm{km}^{2}\right)\end{array}$ & $\%$ & $\begin{array}{c}\text { Area } \\
\left(\mathrm{km}^{2}\right)\end{array}$ & $\%$ & $\begin{array}{c}\text { Loss } \\
(-)\end{array}$ & $\begin{array}{c}\text { Gain } \\
(+)\end{array}$ \\
\hline Built-up & 1 & 23.9 & 3.9 & 36.4 & 6.0 & 0 & 2.1 \\
Forest cover & 2 & 93.2 & 15.4 & 72.9 & 12.0 & 3.4 & 0 \\
Wetland & 3 & 23.2 & 3.8 & 26.1 & 4.3 & 0 & 0.5 \\
Farmland & 4 & 264.7 & 43.7 & 376.2 & 62.1 & 0 & 18.4 \\
$\begin{array}{l}\text { Bushland/ } \\
\text { woodland }\end{array}$ & 5 & 171.5 & 28.3 & & & & \\
Waterbody & 6 & 29.7 & 4.9 & 14.5 & 2.4 & 2.5 & 0 \\
& & & & & & & \\
Total & & 606 & 100 & 606 & 100 & 21 & 21 \\
\hline
\end{tabular}

Table 4. Confusion matrix of the land-cover classification map derived from the 2019

\begin{tabular}{|c|c|c|c|c|c|c|c|c|}
\hline Classified Data & Refere & ce Data & & & & Classified & Producer's & User's \\
\hline Land cover Type & 1 & 2 & 3 & 4 & 5 & Total & Accuracy & Accuracy \\
\hline 1 Built-up & 2004 & 0 & 0 & 0 & 0 & 2004 & 99.01 & 100.00 \\
\hline 2 Forest-Cover & 0 & 3800 & 113 & 0 & 0 & 3913 & 96.67 & 97.11 \\
\hline 3 Wetland & 0 & 0 & 68 & 2803 & 0 & 2871 & 81.77 & 96.56 \\
\hline 4 Farmland & 15 & 63 & 498 & 3676 & 22 & 4274 & 91.63 & 85.99 \\
\hline 5 Bushland/ woodland & 5 & 0 & 0 & 224 & 1253 & 1482 & 98.20 & 84.55 \\
\hline 6 Waterbody & 0 & 0 & 14 & 80 & 1 & 95 & 98.08 & 34.93 \\
\hline Reference Total & 2024 & 3931 & 3428 & 4012 & 1276 & 14639 & & \\
\hline
\end{tabular}

O verall Classification Accuracy $=92.2842 \%$

O verall Kappa Statistics $=0.9006$

Change D etection Assessment

The change detection map shows that the study area underwent a change in land use/ cover over the twenty (20) Years period. The changes showed that forest cover and wood-land have undergone rapid loss with an area covered by $60 \%$, while farmland and wetland also have a gradual change with an area covered by $40 \%$ (Fig 3 ). 


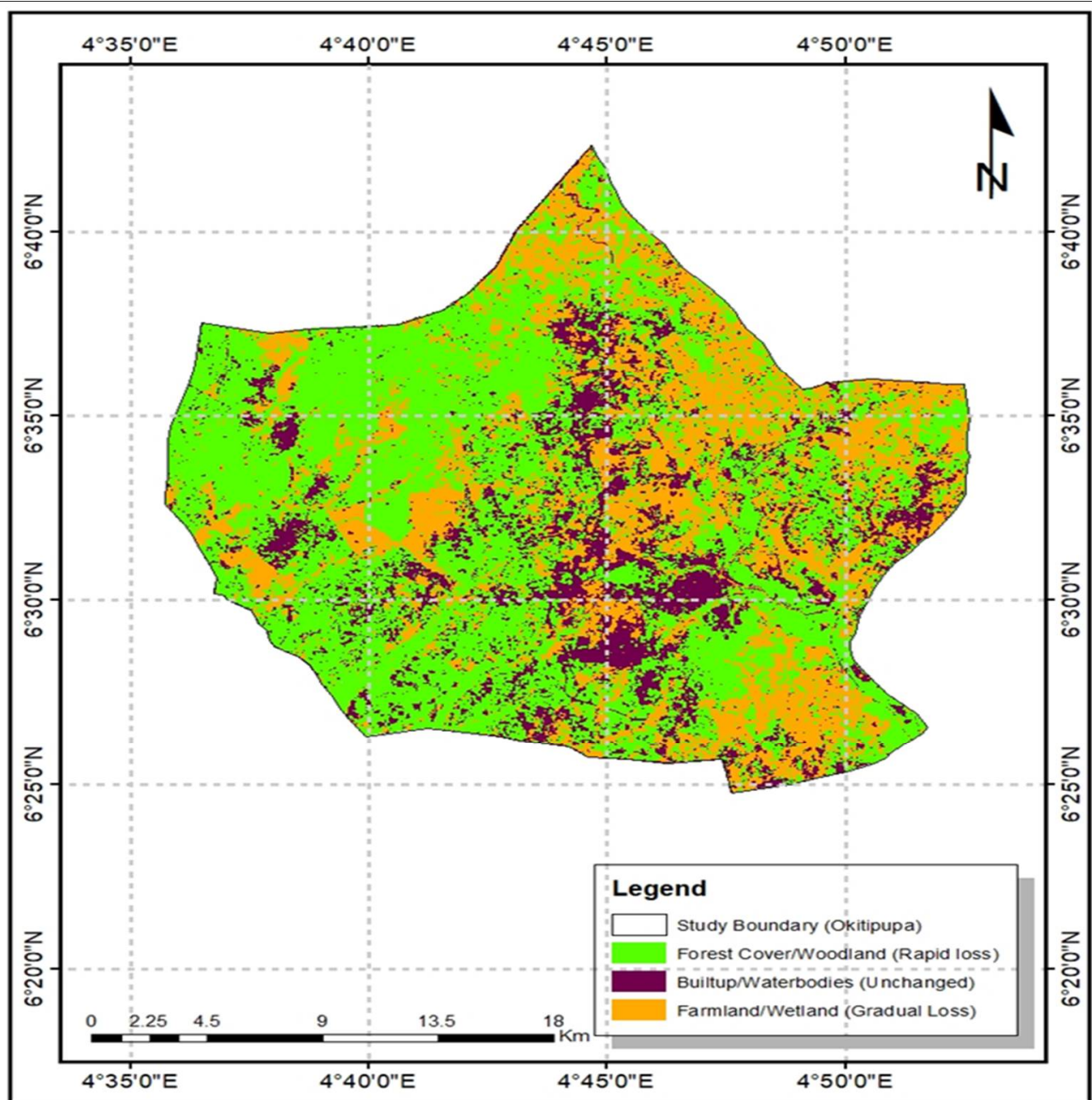

Fig 3: The change detection analysis assessment employed in ENVI 5.1 Environment shows changes in loss over time NDVI Assessment

\section{Vegetation Assessment}

Vegetation indices based on simple combinations of visible and near-infrared reflectance, such as the NDVI have been widely used to monitor vegetation from space, both on regional and global scales. Classification of NDVI values were found to range between - 1 and 1 . However, values above 0.6 indicate dense vegetation and values below 0 indicating no vegetation.
NDVI of the study shows that water surface ranges from 0 to -1 , wetland/ Bareground 0 to 0.1 grassland 0.2 to 0.3 , bushland/ woodland $0.4-0.5$ while vegetation ranges from $>0.56$. Knowledge of the spatial and temporal dynamics of vegetation is essential to understand the impacts of degraded land. Fig 4 shows the NDVI changes between 1999 and 2019. 


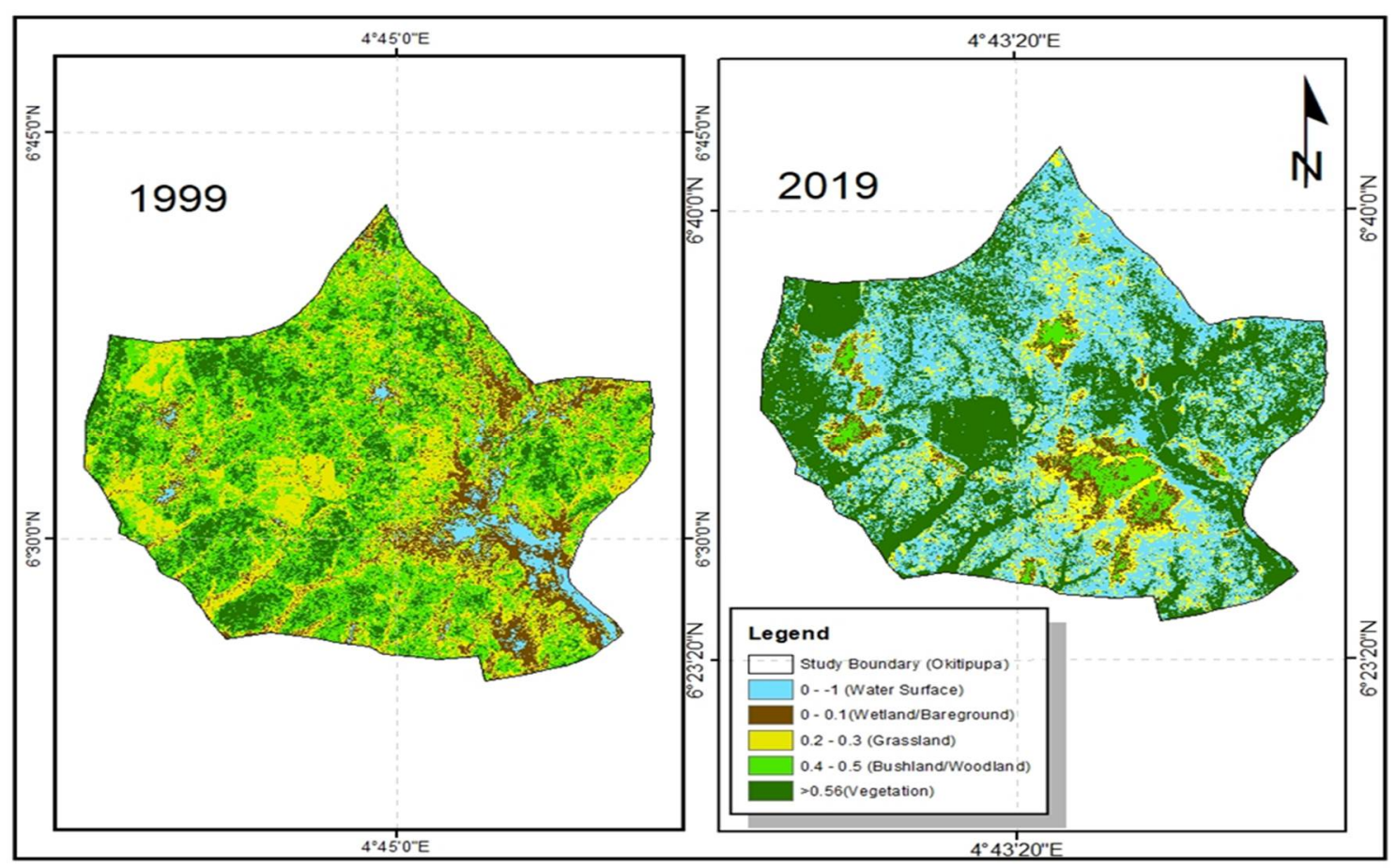

Fig 4: Nomalized difference Vegetation Index change analysis assessment employed in ENVI 5.1.

\section{CONCLUSION}

This study shows that Landsat imagery can be used to monitor land use/ cover change effectively and efficiently. NDVI assessment provides evidence for land-cover change that may well indicate increased/ decreased in the studied area. Specifically, degradation of land use/ cover of the study area is caused by poor land management practices such as slash and burn agriculture, uncontrolled livestock grazing on fragile lands, and unplanned or poorly planned settlements. Also, the sensitivity of the normalized difference vegetation index (NDVI) to land use/ cover has generated an increasing interest in the assessment of intensive and degraded land use/ cover of the study area. The wide variety of land use/ cover changes encountered on the Earth's surface is subjected to continuous environmental and temporal variations changes. The study reveals that Landsat imagery serves as an indispensable technique in assessing land use/ cover change in the study area.

\section{REFERENCES}

Ajayi, R., M.O. Afolabi, E.F. Ogunbodede, A.G. Sunday, 2010. Modeling Rainfall As A Constraining Factor For Cocoa Yield In Ondo State. Am. J. Sci Ind. Res., 1: 127134.

Anderson, J. R. 1976. A LandUseandLand Cover Classification System for Use with Remte Sensor Data. G eological Survey Professional.

Biro, K., Pradhan, B., Buchroithner, M., 
POTENTIALS AND CHARACTERISTICS OF LANDSAT IMAGERY IN RELATION...

and Makeschin, F. Land use/ Land cover Matthiesa W., N, Karimov 2014. Global change analysis and its impact on soil properties in the northern part of $\mathrm{G}$ adarif region, Sudan, Land D egrad.Dev., 24, 90102. https:/ / doi.org/ 10.1002/ ldr.1116, 2013.

Congalton, R.G., Green, 1999. Assessing The Accuracy of Remotely Sensed Data: Principals And Practices (Boca Raton, FL: Lewis).

Ebenezer, T., 2015. Drought, Desertification and The Nigerian Environment: A Review 7, 196-209. Https:/ / D oi.O rg/ 10.5897/ JENE2015.

Gilabert M. A., González-Piqueras J, García-Haro F. J., Meliá J. 2002. "A generalized soil-adjusted vegetation index," RemoteSens Environ 82, 303-310.

Ibrahim, Y.Z., Balzter, J, Kaduk., C.J Tucker, 2015. Land Degradation Assessment Using Residual Trend Analysis of GIMMS NDVI 3g, Soil Moisture And Rainfall In Sub-Saharan West Africa From Food Price Volatility And Spikes: An Overview Of Cost, Causes And Solution Oyerinde, G.T., F.C.C. Hountondji, D Wisser, B, Diekkrüger, A.E, Lawin, A.J, Odofin, A, Afouda, 2015. Hydro-Climatic Changes In The Niger Basin and Consistency of Local Perceptions. Reg. Environ. Chang. 15, 1627-1637. Https:// D oi.O rg/ 10.1007/ S10113-014-0716-7

Oyinloye, R.0. 2010. A Geoinformationbased model for assessing and monitoring forest reserves in southwestern Nigeria. Unpublished Ph.D. Thesis, D epartment of $\mathrm{Ge}$ ography, O bafemi Awolowo University, IleIfe, Nigeria, pp: 337.

Story, M., R.G. Congalton 1986. Accuracy Assessment: A User's Perspective. Photogrammetric Engineering And Remote Sensing, 52, 397-399.

Wilson, E.H., S.A, Sader, 2002. Detection of Forest Harvest Type Using Multiple Dates of Landsat TM Imagery. Remote Sensing of Environment, 80, 385-396.

1982 To 2012 5471-5494. Https://

D oi.O rg/ 10.3390/ Rs70505471

(Manuscipt received 8th Oddber, 2019; accepted 26thMay, 2020). 